\title{
ОРГАНІЗАЦІЯ ІНТЕРАКТИВНОГО НАВЧАННЯ ЯК ЗАСІБ ФОРМУВАННЯ ЗАГАЛЬНОКУЛЬТУРНОЇ КОМПЕТЕНТНОСТІ СТУДЕНТІВ У ПРОЦЕСІ ВИВЧЕННЯ ПСИХОЛОГО-ПЕДАГОГІЧНИХ ДИСЦИПЛІН
}

Микитюк I. А. Організація інтерактивного навчання як засіб формування загальнокультурної компетентності студентів у процесі вивчення психолого-педагогічних дисциплін.

У статті розглядаються основні ознаки інтерактивного навчання й етапи його реалізації. Описуються вимоги та необхідні умови організації інтерактивного навчання у процесі формування загальнокультурної компетентності студентів під час вивчення психологопедагогічних дисциплін.

Ключові слова: інтерактивне навчання, загальнокультурна компетентність, рефлексія.

Микитюк И. А. Организация интерактивного обучения как способ формирования общекультурной компетентности студентов в процессе изучения психолого-педагогических дисциплин.

В статье рассматриваются основные признаки интерактивного обучения и этапы его реализации. Описываются требования и необходимые условия организации интерактивного обучения в процессе формирования общекультурной компетентности студентов во время изучения психолого-педагогических дисциплин.

Ключевые слова: интерактивное обучение, общекультурная компетентность, рефлексия.

Mikityuk I. A. Organization of interactive learning as a way of forming a general cultural competence of students in the study of psycho-pedagogical disciplines.

The article reveals the interactive learning and the main stages of implementation. It describes the requirements and necessary conditions of interactive learning to the formation of the general cultural competence of the students.

Key words: interactive learning, the general cultural competence, reflection.

Результативність формування загальнокультурної компетентності у процесі вивчення психолого-педагогічних дисциплін неможлива без перетворення навчання на активний розумовий процес, тому для активізації емоційно-вольових зусиль студентів доцільно на навчальних заняттях використовувати різноманітні форми взаємодії, інтерактивні технології, які потребують розвитку соціально-рольових здібностей студентів (рольові ігри, дискусії, бесіди, комунікативні тренінги тощо). Формуючи систему завдань, слід ураховувати можливості й індивідуальні особливості студентів, їхній пізнавальний і практичний досвід, труднощі, з якими вони можуть зіткнутися під час пізнавальної діяльності.

Про успішність реалізації окремого напрямку навчальної діяльності студентів можна говорити тоді, коли забезпечуватиметься засвоєння інформації до рівня готовності творчого ії використання в ситуаціях, що моделюють майбутню професійну діяльність.

Аналіз наукових досліджень засвідчує, що важливою умовою, яка стимулює формування загальнокультурної компетентності студентів, сприяє дотриманню єдності теорії й практики в підготовці майбутніх педагогів до роботи культурологічного характеру $\epsilon$ реалізація в навчальному процесі імітаційно-ігрового підходу. Розробленням окресленого підходу, ігрових методів навчання, з'ясуванням ролі ігор, тренінгів, їх значення в навчальному процесі опікувалися А. Ананьєв [1], Л. Виготський [2], Д. Ельконін [10], О. Леонтьєв [8], Г. Селевко [9]. Проблемі залучення майбутніх учителів до активної пізнавальної діяльності присвятили свої праці І. Лернер [3], О. Малихін [4], А. Матюшкін [6], М. Махмутов [7]. Аналіз теоретичних праць науковців дозволяє зробити висновок, що імітаційно-ігровий підхід - це методологічна спрямованість у педагогічній діяльності, яка дозволяє через систему взаємопов'язаних понять імітації та гри, принципів та способів імітаційно-ігрових дій, інтерактивних технологій забезпечити процес професійного становлення особистості, актуалізації процесів самовдосконалення, самоосвіти, саморозвитку студентів засобом реалізації їхньої аналітикооцінювальної та пошуково-практичної діяльності на основі розвитку соціально-рольових здібностей студентів. Отже, суть окресленого підходу полягає у використанні гри, інтерактивних технологій у процесі професійного формування особистості майбутнього вчителя. 
Meта статmi - обгрунтувати актуальність проблеми організації інтерактивного навчання у процесі вивчення психолого-педагогічних дисциплін як засобу формування загальнокультурної компетентності студентів.

Дослідження останніх років і аналіз вишівської практики констатують певну суперечність між потребою суспільства у формуванні творчої особистості вчителя й традиційним характером його підготовки у вищій школі у процесі вивчення психолого-педагогічних дисциплін. Основним недоліком цього $є$ неможливість забезпечення ефективної діяльності випускника в умовах сучасної школи. Важливою умовою, яка стимулює формування загальнокультурної компетентності студентів, сприяє дотриманню єдності теорії й практики в підготовці майбутніх педагогів до роботи культурологічного характеру, $є$ реалізація в навчальному процесі дидактичної інтеграції традиційних методів 3 інноваційними методами навчання засобами інтерактивних технологій (тренінг, рольова гра, дискусія, диспут, дебати тощо).

Розв'язанню проблем, наявних у системі підготовки майбутнього фахівця, сприяє реалізація імітаційно-ігрового підходу, який забезпечує засвоєння культурологічних знань, практичних умінь i навичок, а також сприяє формуванню професійно необхідних особистісних рис. Під час використання інтерактивних технологій, гри у процесі вивчення психолого-педагогічних дисциплін знаходить утілення один 3 основних дидактичних принципів - зв'язку теорії 3 практикою; а саме відсутність такого зв'язку є головною причиною низького рівня готовності студентів до професійної діяльності загалом та до культурологічної діяльності зокрема.

Імітаційно-ігровий підхід на практиці реалізується через дотримання таких принципів:

- принципу індивідуальності, який передбачає створення в імітаційно-ігровій діяльності умов для відтворення своєрідності особистості, іï соціально-рольових здібностей і подальшого розвитку ії індивідуальних особливостей;

- принципу суб'єктності, що полягає в перетворенні студента на суб'єкт предметнопрактичної діяльності, у спрямованості мети, змісту й організації навчальної діяльності на вияв самостійності, ініціативності, творчості;

- принципу новизни, який грунтується на ефекті новизни й робить навчальну інформацію особистісно значимою для студента;

- принципу педагогічної взаємодії, співпраці та співтворчості, який виявляється в загальних узгоджених діях студентів, спрямованих на досягнення рольової перспективи в імітаційнорольовій діяльності, що забезпечує психологічний комфорт, можливість пізнавальної та емоційної стійкості, самовираження й самоствердження їх особистості;

- принципу свободи вибору, що передбачає вільний вибір учасниками імітаційно-ігрової діяльності мети, змісту, форм і способу розв'язання навчальних проблем;

- принципу творчості й успіху, який передбачає нестандартний підхід до розв'язання навчальних завдань і створення для студентів ситуації успіху [4].

Використання імітаційно-ігрового підходу, на думку науковців, забезпечує контроль виведення емоцій, надання студентові можливості самовизначення, сприяє й допомагає розвитку творчої уяви, надає змогу удосконалювати навички співпраці з учнями, можливість висловити власні думки. Учасники навчального процесу за ігровою моделлю перебувають в інших умовах, ніж за традиційного навчання: надається свобода інтелектуальної діяльності, обирається власна роль, висувається припущення про розвиток подій, створюється проблемна ситуація й відшукуються шляхи ії розв'язання.

Імітаційно-ігровий підхід до навчання дозволяє забезпечити активізацію навчальних дій засобами інтерактивних технологій (тренінг, рольова гра, дискусія, диспут, дебати тощо) на основі розвитку соціально-рольових здібностей студентів, надати пізнавальній діяльності студентів творчого характеру, зробити засвоєння досвіду більш емоційним. Його реалізація вимагає від майбутніх фахівців вияву високого рівня активності, супроводжуваної почуттям задоволення від застосування власних інтелектуальних і духовних сил.

У рольовій грі моделюються пізнавальні ситуації, виявляються соціально-рольові здібності, імітуються якості, стани, знання й уміння, необхідні студентам для успішного виконання професійних функцій. Інтерактивні технології дозволяють наблизити навчальний процес до реальних умов професійної діяльності, що забезпечує активність студента й перехід мотивації від пізнавального рівня до професійного. 
Для здійснення інтерактивних технологій необхідне спеціально створене середовище доброзичливої позитивної атмосфери. За такої умови студенти можуть подолати страх перед учнями, розвинути особистісні риси: рішучість, сміливість, цілеспрямованість, ініціативність тощо. Важливим моментом для професійного становлення майбутнього вчителя $\epsilon$ те, що аналізуючи свою участь у грі, дискусії тощо, він має можливість визначити рівень власної загальнокультурної компетентності.

Цей підхід містить умови для підготовки творчого, активного, ініціативного учителя, здатного до самоосвіти й саморозвитку, здатного бачити недоліки своєї підготовки й накреслювати шляхи їх усунення, самостійно ставити професійні завдання та розв'язувати їх. Тому у процесі вивчення психолого-педагогічних дисциплін майбутніх учителів слід залучати до активної творчої професійно спрямованої пізнавальної діяльності, яка б вимагала актуалізації процесів самовдосконалення, самоосвіти, саморозвитку засобом реалізації їхньої аналітико-оцінювальної та пошуково-практичної діяльності. Отже, кожному студенту в процесі активної пізнавальної діяльності слід забезпечити таку позицію, за якої б він здійснював пошук розв'язання певного професійного завдання, обирав методи й засоби, приймав рішення та відповідав за отриманий результат, задля чого доречно використовувати різноманітні форми взаємодії (рольові ігри, дискусії тощо).

Природа загальнокультурної компетентності $є$ такою, що хоч вона $є$ продуктом учіння, але не безпосередньо є його результатом, а наслідком саморозвитку індивіда, його не стільки технологічного, скільки особистісного зростання, цілісної самоорганізації і синтезу діяльнісного й особистісного досвіду. Загальнокультурна компетентентність - це така форма системно побудованих знань, умінь, які зумовлюють особистісну самореалізацію, знаходження тим, хто навчається, свого місця у світі. Тому освіта, що уможливлює формування загальнокультурної компетентності, стає високомотивованою й особистісно зорієнтованою, тобто забезпечує максимальну затребуваність особистісного потенціалу, поглиблюючи взаємозв'язки між освітою і культурою. При цьому регулювальним чинником професійного зростання та творчої активності студента $є$ самосвідомість як досить стала сукупність уявлень і суджень індивіда про самого себе.

Стимулювання позитивної мотивації студентів до культурологічної роботи з учнями потребує творчого проектування та планомірної цілеспрямованої організації навчального процесу, добору адекватних форм і методів навчання, своєчасного діагностування рівнів розвитку в майбутніх педагогів творчих здібностей i умінь, організації i проведення педагогічних практик, самостійної роботи студентів, а також забезпечення загальної зацікавленості проблемою, яка вимагала б від студентів активної діяльності. Тому одне із завдань викладача на всіх етапах становлення студента - допомогти йому знайти себе. За організації викладачем впливу на об'єкт потрібно враховувати те, що студент не народжується суб'єктом діяльності, а стає ним під впливом виховання. Саме викладачі повинні допомогти студентові стати суб'єктом діяльності, в основі якої лежить саморух, самоствердження, самовдосконалення [5].

Відповідно до цього діяльність ВНЗ повинна спрямовуватись на посилення роботи викладача 3 кожним студентом (на основі розвивального характеру всіх форм навчання і виховання) 3 налаштування його внутрішньо-духовного життя на самопізнання й критичну оцінку власних професійно-особистісних якостей. Окрім того, необхідно орієнтувати студентів під час формування загальнокультурної компетентності на отримання тих знань, умінь і навичок, які сприятимуть розвитку й удосконаленню професійно необхідних якостей їхньої особистості.

О. Малихін звертає увагу на те, що протягом навчання у ВНЗ відбувається певний розвиток навчально-пізнавальної діяльності студентів, який є спрямовуючим вектором розвитку їхньої особистості. «Завдання полягає в тому, - зазначає науковець,- щоб уже 3 перших днів перебування у вищій школі готувати студентів до професійного зростання, самоствердження у професійному середовищі; розвивати їхню позитивну навчальну та трудову мотивацію; формувати в них навички самостійної роботи й самоконтролю за ії результатами, здатність адаптуватися до різних ситуацій виробничо-економічного середовища, у якому доведеться жити та працювати» [4, с. 57]. Тож ефективність виявлення індивідуальних якостей особистості в особистісно зорієнтованому освітньому процесі залежить від того, наскільки вдало викладач зможе створити особистісно зорієнтовану ситуацію. У контексті нашого дослідження під такою 
ситуацією слід розуміти діалогічну та рольову (ігрову) взаємодію всіх їі учасників на основі професійного контексту. Отже, тріада «задача - діалог - гра» утворює базовий технологічний комплекс, який створює ціннісно-смислове поле міжсуб'єктного спілкування в особистісно зорієнтованому процесі [1]. Такий підхід забезпечує ситуацію, що сприяє готовності студента до творчої професійної діяльності загалом і формуванню загальнокультурної компетентності студента у процесі вивчення психолого-педагогічних дисциплін зокрема.

У процесі професійної підготовки формуються і розвиваються складники загальнокультурної компетентності фахівця, які надають йому змогу максимально реалізувати свій інтелектуальнотворчій потенціал; застосовувати методи самовиховання і самореалізації, зорієнтовані на систему індивідуальних, національних і загальнолюдських цінностей. Організація інтерактивного навчання у процесі вивчення психолого-педагогічних дисциплін сприяє розвитку соціальнорольових здібностей студентів, що надає змогу майбутнім учителям застосовувати засоби та технології інтеркультурної взаємодії; розробляти і реалізовувати стратегії діяльності, поведінки й кар'єри в умовах міжкультурного суспільства; інтерактивно опановувати та створювати моделі толерантної поведінки й конструктивної діяльності в умовах культурних, мовних, релігійних та інших відмінностей між народами. Отже, організація інтерактивного навчання у процесі вивчення психолого-педагогічних дисциплін допомагає студентам активно включатися до сучасного освітнього та соціального простору, сприяє їхній професійній i соціальній адаптації, ефективному формуванню загальнокультурної компетентності, що безпосередньо пов'язане 3 міжнародними процесами: наближенням вітчизняної освіти до європейської у межах Болонського процесу, глобалізацією та інтернаціоналізацією культурного та інформаційного світового простору.

\section{Література}

1. Ананьев Б. Г. Человек как предмет познания / Борис Герасимович Ананьев. - [3-е изд.]. - СПб : Питер, 2001. - 288 с. 2. Выготский Л. С. Собрание сочинений: в 6 т. / Л. С. Выготский ; [гл. ред. А. В. Запорожец]. - Т. 2 : Проблемы общей психологии. - М. : Педагогика, 1982. -504 с. 3. Лернер И. Я. Состав содержания образования и пути его воплощения в учебнике / И. Я. Лернер // Проблемы школьного учебника. - М. : Просвещение, 1978. - Вып. 6. - С. 63-82. 4. Малихін О. В. Методика викладання у вищій школі: [навч. посіб.] / [ авт.-укл. О. В. Малихін, І. Г. Павленко, О. О. Лаврентьєва, Г. І. Матукова ]. - Сімферополь : ДІАЙПІ, 2011. - 224 с. 5. Малихін О. В. Організація самостійної навчальної діяльності студентів вищих педагогічних навчальних закладів: теоретико-методологічний аспект: [монографія] / О. В. Малихін. - Кривий Ріг : Видавничий дім, 2009. - 307 с. 6. Матюшкин А. М. Проблемные ситуации в мышлении и обучении / Алексей Михайлович Матюшкин. - М. : Педагогика, 1978. - 208 с. 7. Махмутов М. И. Организация проблемного обучения в школе: [кн. для учит.] / Мирза Исмаилович Махмутов. - М. : Просвещение, 1977. - 240 с. 8. Леонтьев А. Н. Деятельность. Сознание. Личность / Алексей Николаевич Леонтьев. - М. : Политиздат, 1977. - 304 с. 9. Селевко Г. К. Современные образовательные технологии: [учеб. пособ.] / Герман Константинович Селевко. - М. : Народное образование, 1998. - 256 с. 10. Эльконин Д. Б. Психология игры / Даниил Борисович Эльконин. - М. : Педагогика, 1978. - 304 с.

Тетяна Мішеніна

\section{ТЕХНОЛОГІЧНИЙ ПІДХІД ДО НАВЧАННЯ У ПРОЦЕСІ ФОРМУВАННЯ ДИДАКТИЧНОЇ КОМПЕТЕНТНОСТІ МАЙБУТНЬОГО ВЧИТЕЛЯ ФІЛОЛОГІЧНИХ СПЕЦАЛЬНОСТЕЙ}

Мішеніна Т. М. Технологічний підхід до навчання у процесі формування дидактичної компетентності майбутнього вчителя філологічних спеціальностей.

У статті розкрито сутність технологічного підходу до навчання у процесі формування дидактичної компетентності майбутнього вчителя філологічних спеціальностей. Розкрито сутнісні характеристики дидактичних категорій: зміст освіти, рівні засвоєння освіти, навчальні ситуації, навчальні завдання. 3 урахуванням опису цілей навчання, видів змісту освіти й рівнів засвоєння подано грунтовний перелік можливих поєднань цілей і видів змісту освіти.

Ключові слова: технологічний підхід, технолого-конструювальна діяльність учителя, дидактична компетентність, майбутні вчителі філологічних спеціальностей. 